\title{
PEROLEHAN GENETIK PADA UJI KLON JATI (Tectona Grandis L.F) UMUR 3 TAHUN DI KHDTK KEMAMPO, SUMATERA SELATAN
}

\author{
Genetic Gains on Clonal Test of Teak (Tectona grandis L. f) \\ at 3 Years Old in KHDTK Kemampo, South Sumaterat \\ Agus Sofyan ${ }^{1}$ Mohammad Na'iem ${ }^{2}$ Sapto Indrioko ${ }^{2}$ \\ 1) Balai Penelitian Kehutanan Palembang \\ Jl. Kol. H. Burlian KM. 6,5 Puntikayu, Po. Box 179, Palembang, Sumatera Selatan \\ Telp./Fax. (0711) 414864 \\ ${ }^{2)}$ Fakultas Kehutanan, Universitas Gadjah Mada
}

Naskah masuk : 5 Agustus 2010; Naskah diterima : 13 Juni 2011

\begin{abstract}
The objective of research were to determine the level of genetic variation, heritability and expected genetic gains based on tree height, diameter and stem form characters. The research was conducted in 3 years old teak plantation, located at KHDTK Kemampo, South Sumatera. Randomized Complete Block Design was applied using 35 clones, 4 blocks and 3 treeplots in a spacing of $3 \times 3 \mathrm{~m}$. The result of the research showed that there were genetic variation among clones, but the variation was relatively low in comparison to other variation sources, i.e. block and interaction between clone and block. The contribution of the genetic component to total variation was relatively low, i.e. $2.49 \%$ for height and $1.73 \%$ for diameter, while the contribution of stem form was relatively higher, i.e. $9.15 \%$. Genetic gain estimation at the age of 3 years was relatively low, because the heritability value was relatively low, i.e. 0.026 (individual) and 0.16 (clone) for height character and 0.02 (individual) and 0.13 (clone) for diameter. But for stem form were relatively high, i.e. 0.09 and 0.39, respectively. Based on an assumption of using the best five clones, the estimation of expected genetic gain at the age of 3 years for a height, diameter, stem form and volume were $1.28 \%, 1.16 \%, 3.43 \%$ and $8.40 \%$, respectively. Genetic correlation between height and diameter was 1.01 (overestimate), while between diameter and stem form was very high, i.e. 0.88 , and between height and stem form was 0.67. These results could be applicable for selection purpose, because it may done based on just one character, i.e. diameter. Selection index of the best five clones of 24, 36, 14, 35 and 11 were $3.073,1.721,1.574,1.430$ and 1.306 respectively.
\end{abstract}

Keywords: Heritability, teak, genetic correlation, genetic gain, clone, genetic variation,

\begin{abstract}
ABSTRAK
Penelitian ini bertujuan untuk mengetahui variasi genetik, taksiran nilai heritabilitas serta peluang perolehan peningkatan genetik dari masing-masing karakter tinggi, diameter dan bentuk batang. Hipotesis yang diajukan adalah : (1) Adanya variasi genetik yang nyata antar klon yang diuji; (2) Adanya korelasi yang tinggi antar karakter; (3) melalui tindakan seleksi akan diperoleh peningkatan genetik. Penelitian dilakukan pada tanaman umur 3 tahun, di lokasi KHDTK Kemampo, Sumatera Selatan. Pertanaman menggunakan Rancangan Acak Lengkap Berblok, dengan 4 blok, 3 treeplot dengan jarak tanam 3 x 3 meter. Jumlah klon yang diuji sebanyak 35 klon. Hasil menunjukkan bahwa terdapat variasi genetik antar klon, namun variasinya relatif rendah jika dibandingkan dengan sumber variasi lainnya yaitu blok dan interaksi antara klon dengan blok. Sumbangan variasi genetik terhadap total variasi relatif rendah yaitu 2,49 \% untuk karakter tinggi dan 1,73\% untuk diameter. Untuk karakter bentuk batang relatif lebih tinggi yaitu sebesar $9,15 \%$. Taksiran peningkatan genetik pada umur 3 tahun relatif rendah, karena taksiran nilai heritabilitas yang diperoleh relatif rendah yaitu sebesar 0,026 (individu) dan 0,16 (klon) untuk karakter tinggi, sebesar 0,02 (individu) dan 0,13 (klon) untuk karakter diameter. Heritabilitas bentuk batang relatif lebih tinggi masing-masing sebesar 0.09 dan 0,39. Dengan asumsi menggunakan 5 klon terbaik, taksiran perolehan genetik yang dapat dicapai pada umur 3 tahun adalah sebesar 1,28\%
\end{abstract}


untuk karakter tinggi, 1,16\% diameter, 3,43\% bentuk batang serta 8,40\% untuk volume. Korelasi genetik antar karakter tinggi dengan diameter adalah sebesar 1,01 (overestimate), sementara korelasi genetik antara diameter dengan bentuk batang sangat tinggi yaitu sebesar 0,88 , karakter tinggi dengan bentuk batang sebesar 0,67 . Hasil ini akan memudahkan pekerjaan seleksi, karena seleksi dapat didasarkan atas satu karakter saja yaitu diameter. Hasil perhitungan berdasarkan indeks seleksi menunjukkan 5 nomor klon terbaik, berturut-turut nomor $24(3,073), 36(1,7210), 14(1,574), 35(1,430)$ dan $11(1,306)$.

Kata kunci : Heritabilitas, jati, korelasi genetik, perolehan genetik, uji klon, variasi genetik

\section{PENDAHULUAN}

Pertambahan jumlah penduduk serta peningkatan taraf hidup manusia telah menyebabkan peningkatan kebutuhan bahan baku kayu, sementara potensi sumber daya alam semakin menurun, sehingga terjadi kesenjangan antara produksi dengan tingkat kebutuhan. Upaya pemenuhan kebutuhan bahan baku kayu telah dilakukan pemerintah melalui program pembangunan Hutan Tanaman Industri (HTI), yang dalam perkembangannya lebih mengarah kepada pemenuhan kebutuhan industri kertas atau pulp. Sementara untuk kebutuhan kayu pertukangan maupun mebeler masih mengandalkan hutan alam.

Sebagaimana halnya jenis-jenis yang berasal dari hutan alam, potensi jenis jati yang dikelola oleh Perum Perhutani juga sudah sangat menurun. Menurut Iskak (2005), kebutuhan kayu jati pada tahun 2005 sebesar 2,4 juta $\mathrm{m}^{3}$, hanya dapat dipenuhi sebesar $400 \mathrm{ribu} \mathrm{m}^{3}$, sehingga masih terdapat kekurangan pasokan sebesar lebih kurang 2 juta $\mathrm{m}^{3}$.

Dengan tingkat kebutuhan bahan baku kayu yang demikian tinggi, pembangunan dan pengembangan hutan tanaman sesungguhnya mempunyai prospek yang cerah, terlebih jenis jati yang sangat populer serta risetnya yang sudah sangat maju (Bhat, 2003), jati merupakan salah satu jenis yang dikembangkan sebagai hutan tanaman yang cukup luas di dunia dan telah ditanam pada lebih dari 36 negara tropis di Asia, Afrika maupun Amerika. Indonesia merupakan negara terbesar kedua yang mempunyai luasan hutan tanaman jati setelah India (ITTO, 2004 dalam Bramasto dan Suita, 2005). Menurut Na'iem (2000), begitu banyak negara yang tertarik mengembangkan jati dikarenakan kualitas kayunya yang bagus, awet serta bernilai ekonomi tinggi, serta sifat silvikulturnya secara umum telah dikuasai.

Saat ini, dengan menggunakan benih atau klon unggul hasil seleksi, telah dikembangkan pengelolaan hutan tanaman dengan daur yang lebih singkat. Beberapa negara yang memproduksi kayu jati berdaur pendek adalah Bangladesh, India, Thailand, Ghana, Myanmar, Nigeria, Brazil dan Indonesia (Siregar dan Mansur, 2004).

Tujuan umum penelitian ini adalah untuk mendukung upaya pengembangan perhutanan klon berdaur pendek dengan produktivitas tinggi. Adapun tujuan khususnya adalah untuk mengetahui variasi genetik antar klon, heritabilitas, korelasi genetik serta peningkatan genetik masing-masing karakter pertumbuhan.

\section{BAHAN DAN METODE}

\section{A. Bahan dan Lokasi Penelitian}

Penelitian dilakukan pada pertanaman uji klon jati berumur 3 tahun dengan jumlah seedlot sebanyak 35 klon yang berasal dari 6 populasi (Gunung Kidul, Wono giri, Madiun, Cepu, Muna dan Thailand), di Kawasan Hutan dengan Tujuan Khusus (KHDTK) Kemampo, Kabupaten Banyuasin, Sumatera Selatan. Penelitian dilakukan pada bulan Januari - Desember 2008.

\section{B. Metode Penelitian}

\section{Rancangan penelitian}

Rancangan penelitian yang digunakan dalam uji klon jati adalah Rancangan Acak Lengkap Berblok (RCBD) dengan 4 blok sebagai ulangan, masing-masing unit terdiri atas 3 treeplot, dengan jumlah seedlot sebanyak 35 klon yang berasal dari 6 populasi (Gunung Kidul, Wonogiri, Madiun, Cepu, Muna dan Thailand). Jarak tanam $3 \mathrm{~m} \times 3 \mathrm{~m}$.

\section{Variabel yang diukur}

Tanaman diukur pada umur 3 tahun. Variabel yang diukur adalah sifat atau karakter pertumbuhan tanaman (tinggi tanaman, diameter batang setinggi dada), volume kayu serta bentuk batang (Cotterill dan Dean, 1990). 


\section{Analisis data}

Data hasil pengukuran dianalisis dengan menggunakan analisis varians, dengan model analisis varians (linear model) yang digunakan adalah sebagai berikut (Steel and Torrie, 1991):

$$
Y_{i j k l}=\mu+B_{i}+P_{j}+K_{k}\left(P_{j}\right)+B K_{i k}+E_{i j k l}
$$

Keterangan:

Yijkl = Pengamatan pohon pada blok ke i, Populasi ke j, klon ke k, individual ke $l$

$\mu \quad=$ Rerata umum

$\mathrm{Bi}=$ Efekblokke $\mathrm{i}$

$\mathrm{P}_{\mathrm{j}} \quad=$ Efek Populasi ke $\mathrm{j}$

$\mathrm{K}_{\mathrm{k}}\left(\mathrm{P}_{\mathrm{j}}\right)=$ Efek klon ke $\mathrm{k}$ dalam populasi ke $\mathrm{j}$

$\mathrm{BK}_{\mathrm{ik}}=$ Efek interaksiblok ke i dan klon ke k

$\mathrm{E}_{\mathrm{ijkl}}=$ Random error pada pengamatan ke $i j k l$

Untuk mengetahui parameter genetik dilakukan melalui penaksiran terhadap nilai heritabilitas, perolehan genetik serta korelasi genetik antar sifat pertumbuhan.

Nilai heritabilitas yang dihitung adalah nilai heritabilitas individu atau klon, yang ditaksir melalui komponen varians yang diperoleh dari hasil analisis varians. Wright (1976) dan Zobel dan Talbert (1984), menggunakan rumusan taksiran nilai heritabilitas dengan materi vegetatif(klon), sebagai berikut :

$$
\begin{aligned}
h_{i}^{2} & =\frac{{ }_{k}^{2}}{2_{k}{ }_{k b}^{2} 2_{e}^{2}} \text {, dan } \\
H_{k}^{2} & =\frac{{ }_{k}^{2}}{{ }_{k}\left({ }_{k b}^{2} / B\right)}\left({ }_{e}^{2} / N B\right)
\end{aligned}
$$

Keterangan :

$h_{i}^{2}=$ Nilai heritabilitas individu (ramet)

$H_{k}^{2}=$ Nilai heritabilitas klon

${ }_{k}^{2}=$ Komponen varians klon

${ }_{e}^{2}=$ Komponen varians error

${ }_{k b}^{e}=$ komponen varians interaksi klon-blok

$\mathrm{B}=$ Jumlahblok

$\mathrm{N}=$ jumlah ramet per plot

Untuk menduga besarnya perolehan genetik digunakan rumus menurut Zobel dan Talbert (1984) :

$$
\mathrm{G}=\mathrm{H}^{2} \times \mathrm{S} \text { atau } \mathrm{G}=\mathrm{H}^{2} \times \text { ix } p
$$

Keterangan:

$\mathrm{G}=$ taksiran perolehan genetik

$\mathrm{H}^{2}=$ heritabilitas
$\mathrm{S}=$ diferensial seleksi

$\mathrm{i}=$ intensitas seleksi (Becker, 1992)

${ }_{p}=$ standart deviasi phenotipe

Analisis korelasi genetik dilakukan untuk mengetahui hubungan antara sifat tinggi dan diameter secara genetis, yang dilakukan deengan menggunakan rumus menurut Zobel and Talbert (1984) :

$$
r_{G} \frac{k(x y)}{\sqrt{\left(_{\left.k(x) x^{2}{ }_{k(y)}\right)}\right.}}
$$

Keterangan :

$r_{G} \quad=$ korelasi genetik

${ }_{2 k(x)}=$ komponen kovarians untuk sifat $\mathrm{x}$ dan $\mathrm{y}$

${ }_{k(x)}^{2}=$ komponen varians untuk sifat $\mathrm{x}$

${ }_{k(y)}^{k(x)}=$ komponen varians untuk sifaty

Selanjutnya besarnya komponen kovarian untuk dua sifat tersebut ( $\mathrm{x}$ dan $\mathrm{y}$ ) dapat dihitung dengan rumus (Fins et, al. 1982) yaitu sebagai berikut:

$$
k(x y)=0,5\left(\begin{array}{ccc}
2 & 2 \\
k(x+y) & { }_{k x}-{ }_{k y}
\end{array}\right)
$$

Keterangan: ${ }_{k(x+y)}^{2}=$ komponen varians untuk sifat $x$ dan $y$.

\section{HASIL DAN PEMBAHASAN}

\section{A. Persen Hidup dan Pertumbuhan}

Daya adaptasi keseluruhan klon pada umur 3 tahun nampak menunjukkan hasil yang sangat baik, hal ini ditandai dengan tingginya nilai rerata persen hidup yaitu sebesar $84,52 \%$ serta pertumbuhan tanaman yang sangat baik dibandingkan dengan rerata pertumbuhan pada beberapa uji klon jati lainnya, sebagaimana disajikan dalam Tabel 1.

Perbedaan pertumbuhan selain disebabkan oleh perbedaan materi (klon), juga dapat disebabkan oleh perbedaan faktor lingkungan tempat tumbuh (edafis) yang terkait jenis dan kesuburan tanah, intensitas pemeliharaan serta faktor iklim (klimatis) terutama curah hujan. Menurut Sheldbourne (1972) dan Goddart (1979) dalam Zobel dan Talbert (1984), faktor lingkungan edafis memberikan pengaruh yang lebih kuat terhadap pertumbuhan dibanding dengan faktor iklim atau klimatis. 
Tabel (Table) 1. Rerata pertumbuhan uji klon jati di KHDTK Kemampo serta beberapa hasil uji klon pada lokasi lainnya (Average of growth clonal test of teak in KHDTK Kemampo and others location)

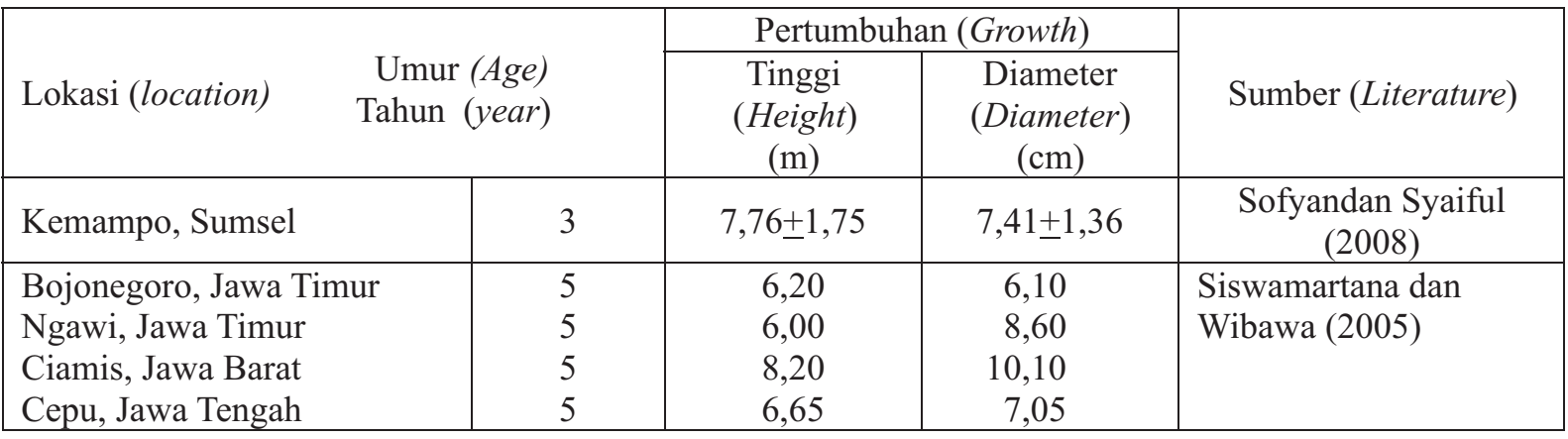

\section{B. Variasi Genetik}

Hasil analisis varians, sebagaimana disajikan pada Tabel 2, menunjukkan perbedaan yang sangat nyata pada sumber variasi klon, hasil ini mengindikasikan adanya variasi genetik antar klon. Adanya variasi genetik akan memberikan peluang dalam meningkatkan perolehan genetik melalui tindakan seleksi terhadap klon-klon terbaik.

Hasil pada Tabel 2 juga menunjukkan bahwa sumber variasi blok dan interaksi mempunyai pengaruh yang sangat nyata bagi pertumbuhan. Hasil interaksi yang sangat nyata mengindikasikan bahwa hasil pertumbuhan tanaman bukan hasil dari kinerja klon atau genetik semata, namun merupakan hasil dari interaksi antara faktor genetik dengan faktor lingkungannya (Kramer \& Kozlowski, 1979). Menurut Matheson dan Raymond (1984) penelitian yang menggunakan bahan atau materi vegetatif ( $k$ lon) seringkali dihasilkan interaksi yang sangat kuat antara klon dengan faktor lingkungannya. Hal tersebut terjadi karena materi klon bersifat sangat reaktif terhadap kondisi lingkungan tempat tumbuh, terutama unsur phosfor, boron dan sulfur (Windsor dan Kelly, 1971 dalam Matheson dan Raymond, 1984).

Dengan adanya variasi antar klon, maka terbuka peluang untuk memperoleh peningkatan genetik pada generasi berikutmya. Namun demikian seberapa besar peningkatan yang dapat diperoleh, sangat tergantung pada besarnya proporsi sumbangan variasi faktor genetik terhadap variasi total. Untuk mengetahui besarnya proporsi variasi yang disebabkan oleh faktor genetik serta faktor lainnya, perlu dilakukan analisis komponen varians. Hasil perhitungan taksiran komponen varians selengkapnya disajikan dalam Tabel 3. Besarnya taksiran komponen varians menggambarkan besarnya proporsi sumbangan (kontribusi) setiap sumber variasi terhadap variasi total.

Tabel(Table) 2. Hasil analisis varian pertumbuhan uji klon jati pada umur 3 tahun (analysis of variance for growth on 3 years measurement in clonal test of teak)

\begin{tabular}{|c|c|c|c|c|c|c|}
\hline \multirow[b]{2}{*}{$\begin{array}{l}\text { Umur } \\
(\text { Age })\end{array}$} & \multirow{2}{*}{$\begin{array}{l}\text { Sumber } \\
\text { Variasi } \\
\text { (Source of } \\
\text { variance) }\end{array}$} & \multirow{2}{*}{$\begin{array}{c}\text { Derajat } \\
\text { Bebas } \\
(d f)\end{array}$} & \multicolumn{4}{|c|}{$\begin{array}{c}\text { Nilai rerata kuadrat tengah } \\
\text { (Mean square) }\end{array}$} \\
\hline & & & $\begin{array}{l}\text { Tinggi } \\
(\text { Height })\end{array}$ & $\begin{array}{l}\text { Diameter } \\
\text { (Diameter) }\end{array}$ & $\begin{array}{l}\text { Volume } \\
\text { (Volume) }\end{array}$ & $\begin{array}{c}\text { Bentuk } \\
\text { Batang } \\
\text { (Stem form) }\end{array}$ \\
\hline \multirow{4}{*}{$\begin{array}{l}3 \text { Tahun } \\
\text { (3 Years) }\end{array}$} & $\begin{array}{l}\text { Blok } \\
\text { Populasi }\end{array}$ & $\begin{array}{l}3 \\
5\end{array}$ & $\begin{array}{c}14,5295^{* *} \\
1.3971^{\text {ns }}\end{array}$ & $\begin{array}{c}27,3177^{* *} \\
1,4923^{\mathrm{ns}}\end{array}$ & $0,001308^{* *}$ & $0,7911^{\mathrm{ns}}$ \\
\hline & Klon & 29 & $2,7896 * *$ & $2,5148 * *$ & $0,000135^{* *}$ & $3,0574 *$ \\
\hline & Klon x Blok & 101 & $2,2789 * *$ & $2,1296^{* *}$ & $0,000165^{* *}$ & $1,7826^{* *}$ \\
\hline & Error & 206 & 1,2016 & 1,2969 & 0,000112 & $0,8293 * *$ \\
\hline
\end{tabular}

Keterangan (Remarks) : * = berbeda nyata pada taraf uji 0,05 (Significant at 0,05 level)

$* *=$ berbeda nyata pada taraf uji 0,01 (Significant at 0,01 level)

$\mathrm{ns}=$ berbeda tidak nyata (Non-significant) 
Tabel (Table) 3. Taksiran komponen varians dan proporsi sumbangan (\%) sumber variasi terhadap variasi total pada umur 3 tahun (The estimated of proportion and variance component of source of variance on 3 years)

\begin{tabular}{|c|c|c|c|c|c|c|c|c|}
\hline $\begin{array}{l}\text { Sumber } \\
\text { Variasi } \\
\text { (Source of } \\
\text { variance) }\end{array}$ & \multicolumn{2}{|c|}{$\begin{array}{l}\text { Karakter tinggi } \\
\quad(\text { Height })\end{array}$} & \multicolumn{2}{|c|}{$\begin{array}{l}\text { Karakter diameter } \\
\text { (Diameter) }\end{array}$} & \multicolumn{2}{|c|}{$\begin{array}{c}\text { Kombinasi } \\
\text { tinggi x diameter } \\
\text { (Combination of height } \\
x \text { diameter) }\end{array}$} & \multicolumn{2}{|c|}{$\begin{array}{l}\text { Bentuk batang } \\
\text { (stem form) }\end{array}$} \\
\hline Umur & Tkv & $\%$ & Tkv & $\%$ & Tkv & $\%$ & Tkv & $\%$ \\
\hline${ }^{2}{ }_{b}$ & 0,1408 & 7,83 & 0,2914 & 15,01 & 0,8465 & 12,97 & 0,0129 & 0,97 \\
\hline 2 & $-0,0326$ & $-1,80$ & $-0,0240$ & $-1,24$ & $-0,1431$ & $-2,19$ & 0,0 & 0,0 \\
\hline${ }^{2}(\mathrm{sb})$ & 0,0448 & 2,49 & 0,0337 & 1,73 & 0,1577 & 2,42 & 0,1218 & 9,15 \\
\hline $2 \mathrm{~kb}$ & 0,4441 & 24,69 & 0,3435 & 17,69 & 1,5330 & 23,50 & 0,3929 & 29,52 \\
\hline${ }_{e}^{2}$ & 1,2016 & 66,80 & 1,2960 & 66,79 & 4,1300 & 63,30 & 0,8293 & 62,30 \\
\hline $2_{\text {total }}$ & 1,7988 & 100,00 & 1,9410 & 99,98 & 6,5238 & 100,00 & 1,3310 & 100,00 \\
\hline
\end{tabular}

Keterangan $\left(\right.$ Remarks) : $\mathrm{Tkv}=$ taksiran komponen varians (variances component estimate), ${ }^{2}=\mathrm{komponen}$ varian, $\mathrm{b}=\mathrm{blok}$ (block), $\mathrm{p}=$ populasi (population), $\mathrm{k}=\mathrm{klon}($ clon $), \mathrm{kb}=$ interkasi klon $\mathrm{x}$ blok (interaction clon $x$ block), $\mathrm{e}=$ error, $\%=$ persentase dari total variasi (presntation of variation total)

Hasil analisis pada Tabel 3 menunjukkan bahwa komponen varians klon (komponen varians genetik) memberikan sumbangan (kontribusi) sangat kecil terhadap variasi total, yaitu masing-masing sebesar 2,49\%, 1,73\% dan $9,15 \%$ untuk karakter tinggi, diameter dan bentuk batang. Hasil ini menggambaran bahwa pada umur 3 tahun, pengaruh faktor genetik terhadap pertumbuhan relatif masih sangat kecil. Sementara komponen varians interaksi masingmasing sebesar 24,69\%, 17,50\% dan 23,50 untuk karakter tinggi, diameter dan kombinasi kedua sifat tersebut. Hasil ini memberikan gambaran bahwa pada umur 3 tahun pengaruh faktor genetik dalam pertumbuhan tanaman masih relatif sangat kecil.

\section{Heritabilitas}

Heritabilitas merupakan parameter yang mengambarkan seberapa besar sifat-sifat induk diwariskan kepada keturunannya dan merupakan suatu hal sangat penting, karena terkait erat dengan perolehan genetik serta strategi pemuliaan pohon dalam memperoleh peningkatan genetik (Zobel dan Talbert, 1984). Heritabilitas yang tinggi menunjukkan adanya peluang perolehan genetik yang besar.

Besarnya nilai heritabilitas yang diperoleh berdasarkan nilai-nilai komponen varians dari masing-masing karakter, selengkapnya disajikan pada Tabel 4.

Dari hasil analisis pada Tabel 4 menunjukkan bahwa untuk semua variabel/karekter yang diukur, secara umum dapat dikatakan mepunyai nilai heritabilitas yang relatif rendah, baik heritabilitas individu maupun famili. Menurut Hardiyanto (1994) dalam Leksono (1994) nilai heritabilitas untuk famili (klon) sebesar 0,40 - 0,60 dikategorikan sedang, kurang dari 0,40 adalah rendah dan lebih dari 0,60 termasuk dalam kategori tinggi.

Tabel(Table) 4. Taksiran nilai heritabilitas untuk semua karakter pada umur 3 tahun (The estimated of heritability of all character's on 3 year's).

\begin{tabular}{|c|c|c|c|c|}
\hline \multirow[b]{2}{*}{ Umur (Age) } & \multicolumn{4}{|c|}{ Karakter (Character) } \\
\hline & $\begin{array}{r}\text { Tinggi } \\
\text { (Height) } \\
h_{i}^{2} \quad h_{k}^{2} \\
\end{array}$ & $\begin{array}{c}\text { Diameter } \\
\text { (Diameter) } \\
h_{i}^{2} \quad h_{k}^{2}\end{array}$ & $\begin{array}{c}\text { Volume } \\
(\text { Volume) } \\
h_{i}^{2} \quad h_{k}^{2}\end{array}$ & $\begin{array}{c}\text { Bentuk batang } \\
(\text { Stem form }) \\
h_{i}^{2} \quad h_{k}^{2}\end{array}$ \\
\hline $\begin{array}{l}3 \text { Tahun } \\
\text { (3 years) }\end{array}$ & 0,03 & 0,02 & 0,05 & 0,09 \\
\hline
\end{tabular}

Keterangan (Remarks) $: \mathrm{h}_{\mathrm{i}}^{2}=$ heritabilitas individu (Individual heritability)

$\mathrm{h}_{\mathrm{k}}^{2}=$ heritabilitas klon (Clones heritability) 
Rendahnya nilai heritabilitas pada uji klon ini dapat disebabkan oleh beberapa hal, antara lain karena rendahnya nilai komponen varians genetik $\left(\begin{array}{c}2 \\ k\end{array}\right)$, dibanding dengan nilai komponen varians interaksi $\left({ }_{\mathrm{kb}}^{2}\right)$. Menurut Shelbourne (1972) bahwa pengaruh interaksi yang menghasilkan komponen varians $\left({ }_{\mathrm{kb}}^{2}\right)$ yang jauh lebih besar daripada komponen varians genetiknya, dapat menjadi masalah serius dalam perolehan genetiknya, karena pada kondisi tersebut nilai heritabilitasnya menjadi sangat rendah. Sementara menurut Russel dan Libby (1986), jumlah unit percobaan (ramet per klon) serta jumlah replikasi (blok) juga sangat berpengaruh terhadap nilai heritabilitas, semakin banyak jumlah unit percobaan dan replikasi, maka nilai heritabilitas akan semakin besar. Hasil penelitian yang dilaporkan Russel dan Libby (1986) menunjukkan bahwa penambahan jumlah unit percobaan pada uji klon Pinus radiata, telah meningkatkan nilai heritabilitas yang signifikan.

Dalam uji klon ini jumlah unit percobaan yang relatif sedikit yaitu 3 treeplot dengan 4 blok sebagai ulangan, dapat menyebabkan nilai heritabilitasnya menjadi rendah. Hal lain yang dapat menyebabkan rendahnya heritabilitas menurut Kuntiyati (1995) dalam Wibowo (2002) adalah karena sifat-sifat kuantitatif (tinggi, panjang, lebar) banyak dikendalikan oleh gen minor yang porsi pengaruhnya sangat kecil dan berbeda-beda, sehingga sifat-sifat tersebut lebih mudah dipengaruhi oleh faktor lingkungan.

\section{Perolehan Genetik}

Taksiran perolehan genetik merupakan suatu nilai kuantitatif dari respon populasi atas adanya seleksi pada populasi tersebut. Seberapa besar perolehan genetik dapat dicapai, sangat erat kaitannya dengan nilai heritabilitas masingmasing karakter atau sifat. Taksiran nilai heritabilitas yang tinggi akan menghasilkan perolehan genetik yang tinggi (besar), jika nilai heritabilitasnya rendah, maka perolehan genetik juga relatif rendah. Perolehan genetik juga dipengaruhi oleh intensitas seleksi.

Dalam penelitian ini perolehan genetik dihitung dengan asumsi bahwa dari 35 klon yang diuji, akan diseleksi sebesar $30 \%$ (10 klon), 20 $\%$ (7 klon) dan $15 \%$ (5 klon), dengan nilai intensitas seleksi masing-masing sebesar 1,527, 1,360 dan 1,160 sesuai tabel intensitas seleksi menurut Becker (1992). Dengan intensitas seleksi tersebut, diperoleh hasil perhitungan taksiran perolehan genetik sebagaimana disajikan pada Tabel 5.

Hasil di atas menunjukkan bahwa perolehan genetik untuk karakter tinggi $(0,98$ $1,28 \%)$ dan diameter $(0,81-1,16 \%)$, relatif rendah dibanding bentuk batang (3,03-3,43\%) dan volume $(3,55-8,40 \%)$. Hal ini disebabkan karena nilai komponen varians bentuk batang yang cukup besar, yaitu hampir 4 kali lebih besar dibanding nilai komponen varians genetik (klon) untuk karakter tinggi dan 5 kali lebih besar dibanding nilai komponen varians genetik untuk karakter diameternya (Tabel 3), begitu pula

Tabel (Table) 5. Taksiran perolehan genetik dan peningkatan sifat pada Uji Klon Jati pada umur 36 bulan, di KHDTK Kemampo. Sumsel (The estimated of genetic gain on clonal test of teak at KHDTK Kemapo, South Sumatera)

\begin{tabular}{|c|c|c|c|c|}
\hline $\begin{array}{l}\text { Karakter } \\
\text { (Character) }\end{array}$ & $\begin{array}{c}\text { Rerata } \\
\text { (Average) }\end{array}$ & $\begin{array}{c}\text { Jumlah klon } \\
\text { (Number of clone) }\end{array}$ & $\begin{array}{c}\text { Perolehan genetik } \\
(\%) \\
\text { (Genetic gain) }\end{array}$ & $\begin{array}{l}\text { Peningkatan sifat } \\
\text { (Improve of character) }\end{array}$ \\
\hline $\begin{array}{l}\text { Tinggi } \\
(\text { height })\end{array}$ & 7,764 (m) & $\begin{array}{r}5 \\
7 \\
10\end{array}$ & $\begin{array}{l}1,28 \\
1,14 \\
0,98\end{array}$ & $\begin{array}{l}7,86(\mathrm{~m}) \\
7,85(\mathrm{~m}) \\
7,84(\mathrm{~m})\end{array}$ \\
\hline $\begin{array}{l}\text { Diameter } \\
\text { (diameter) }\end{array}$ & $7,412(\mathrm{~cm})$ & $\begin{array}{r}5 \\
7 \\
10\end{array}$ & $\begin{array}{l}1,16 \\
0,89 \\
0,81\end{array}$ & $\begin{array}{c}7,49(\mathrm{~cm}) \\
7,48(\mathrm{~cm}) \\
7,47(\mathrm{~cm})\end{array}$ \\
\hline $\begin{array}{l}\text { Bentuk batang } \\
\text { (stem form) }\end{array}$ & 3,91 & $\begin{array}{r}5 \\
7 \\
10\end{array}$ & $\begin{array}{l}3,43 \\
3,40 \\
3,03\end{array}$ & $\begin{array}{l}4,044 \\
4,043 \\
4,028\end{array}$ \\
\hline $\begin{array}{l}\text { Volume } \\
\text { (volume) }\end{array}$ & $0,025 \mathrm{~m}^{3} / \mathrm{phn}$ & $\begin{array}{r}5 \\
7 \\
10\end{array}$ & $\begin{array}{c}8,40 \\
6,00 \\
3,55\end{array}$ & $\begin{array}{l}0,0271 \mathrm{~m}^{3} / \mathrm{phn} \\
0,0265 \mathrm{~m}^{3} / \mathrm{phn} \\
0,0258 \mathrm{~m}^{3} / \mathrm{phn}\end{array}$ \\
\hline
\end{tabular}


halnya dengan nilai heritabilitasnya yang jauh lebih besar yaitu 0,30 untuk bentuk batang dan 0,39 untuk volume, sementara untuk karakter tinggi dan diameter masing-masing sebesar 0,16 dan 0,13 (Tabel 4). Dari hasil tersebut nampak bahwa dengan nilai komponen varians genetik serta heritabilitas yang lebih besar, maka peluang peningkatan genetik yang dapat diperoleh akan menjadi lebih besar. Peningkatan genetik juga menjadi semakin tinggi dengan semakin tingginya tingkat intensitas seleksi (Tabel 5).

Mengingat bahwa umur tanaman masih relatif sangat muda yaitu 3 tahun, dimana pertumbuhan tanaman masih sangat dipengaruhi oleh faktor lingkungan, maka kemungkinan terjadinya perubahan pada koefisien komponen varians genetik serta heritabilitasnya pada saat umur tanaman bertambah (lebih tua) masih sangat dimungkinkan dapat berubah, dengan demikian peluang perolehan genetik yang lebih besar tetap bisa diharapkan.

\section{E. Korelasi Genetik}

Korelasi genetik mempunyai arti yang sangat penting dalam program pemuliaan pohon, terutama untuk mengembangkan dua karakter atau sifat yang berbeda dengan berdasarkan pada penerapan seleksi atas satu karakter, dengan harapan secara tidak langsung akan dapat memperbaiki karakter yang lainnya (Zobel dan Talbert, 1984). Koefisien korelasi genetik menggambarkan seberapa besar sesungguhnya hubungan keeratan antar karakter secara genetik. Hasil perhitungan korelasi genetik antar karakter (diameter dan tinggi) selengkapnya disajikan pada Tabel 6.

Korelasi genetik antar sifat tinggi dengan diameter sebesar 1,01 merupakan nilai yang bersifat overestimate, hal ini disebabkan karena tidak seimbangnya rasio antara komponen varians genetik dengan komponen varians interaksinya (Matheson dan Raymond,1984 ; Isik dan Kleinschmidt, 2005). Korelasi antar karakter tinggi dengan bentuk bantang menunjukkan hubungan korelasi yang cukup kuat, yaitu sebesar 0,67. Sementara korelasi antar karakter diameter dengan bentuk batang sebesar 0,88 . Hasil ini menggambarkan bahwa karakter diameter mempunyai pengaruh positif yang kuat terhadap karakter tinggi maupun bentuk batang. Dari hasil ini dapat dikatakan bahwa apabila hendak melakukan seleksi, maka seleksi cukup didasarkan pada satu karakter yaitu diameter, karena dengan hanya memprioritaskan pada karakter diameter sesungguhnya akan diikuti dengan perbaikan karakter tinggi dan bentuk batangnya. Dengan demikian pelaksanaan seleksi akan menjadi lebih efisien, baik dari sisi anggaran maupun waktu. Namun demikian untuk uji klon ini, karena korelasi genetik yang diperoleh dari tanaman yang masih sangat muda dimana kinerja genetik masih relatif labil (belum cukup stabil), maka masih perlu untuk dikaji hubungan korelasinya dalam beberapa tahun ke depan saat umur tanaman relatif lebih tua, saat kinerja genetik tanaman sudah relatif stabil. Hal tersebut sangat penting guna diperolehan peningkatan genetik sebagaimana yang diharapkan.

Tabel(Table) 6. Korelasi genetik antar sifat pada uji klon jati umur 3 tahun di KHDTK Kemampo, Sumatera Selatan (genetic correlation on clonal test of teak at KHDTK Kemampo, South Sumatera)

\begin{tabular}{|c|c|c|c|}
\hline \multirow{2}{*}{$\begin{array}{l}\text { Umur } \\
\text { (Age) }\end{array}$} & \multicolumn{3}{|c|}{$\begin{array}{c}\text { Karakter/sifat } \\
\text { (Character) }\end{array}$} \\
\hline & & $\begin{array}{l}\text { Tinggi } \\
(\text { Height })\end{array}$ & $\begin{array}{c}\text { Bentuk batang } \\
\text { (stem form) }\end{array}$ \\
\hline & $\begin{array}{l}\text { Tinggi } \\
(\text { Height })\end{array}$ & - & 0,67 \\
\hline $\begin{array}{l}3 \text { Tahun } \\
\text { (3 Years) }\end{array}$ & $\begin{array}{l}\text { Diameter } \\
\text { (Diameter) }\end{array}$ & 1,01 & 0,88 \\
\hline
\end{tabular}

\section{KESIMPULAN}

1. Dari 35 klon yang diuji terdapat variasi genetik antar klon, namun sumbangan variasinya terhadap total variasi relatif sangat rendah yaitu $2,49 \%$, untuk karakter tinggi, $1,73 \%$ diameter dan $9,15 \%$ untuk karakter bentuk batang.

2. Korelasi genetik antara karakter tinggi dengan diameter sebesar 1,01 (overestimate), 
sementara korelasi antar karakter tinggi dengan bentuk batang serta diameter dengan bentuk batang, masing-masing sebesar 0,67 untuk dan 0,88 .

3. Taksiran peningkatan genetik yang diperoleh adalah sebesar $1,28 \%$ dan $1,16 \%$ untuk karakter tinggi dan diameter, 3,43\% dan 8,40 $\%$ untuk bentuk batang dan volume, dengan asumsi menggunakan 5 klon terbaik.

\section{DAFTAR PUSTAKA}

Becker, W. A. 1992. Manual of Quantitative Genetics. Academic Enterprise. Pullman. USA. Fifth Edition.

Bhat, K.M. 2003. Quality Concerns of Sustainable Teak Wood Chain. Quality Timber Product of Teak From Sustainable Forest Management. Proceeding of The International Conference on Quality Timber of Teak From Sustainable Forest Management. Peechi, India 2-5 Desember 2003.

Bramasto, Y. dan Suita, E. 2005. Variasi Pertumbuhan Tanaman Jati dari Berbagai Klon di Kebun Percobaan Rumpin. Prosiding Seminar Nasinal. Dengan IPTEK Membangun Hutan Tanaman Demi Kemakmuran Bangsa dan Terciptanya Kelestarian Lingkungann. Pusat Litbang Hutan Tanaman. Yogjakarta, 2005.

Cotterill, P.P. dan C.A. Dean. 1990. Successful Tree Breeding With Index Selection. CSIRO Division of Forestry and Forest Product. Australia.

Isik, K. dan Kleinschmit, J. 2005. Similarties and effectiveness of tes eninvironments in selecting and deploying desirable genotypes. Theor Appl Genet (2005) 110 : 311-322.

Iskak, M. 2005. Produktivitas Tegakan Jati JPP Intensif sampai dengan Umur 20 Tahun ke Depan. Seperempat Abad Pemuliaan Jati Perum Perhutani. Pusat Pengembangan Sumber Daya Hutan Perum Perhutani.

Kramer, P.J and T.T. Kozlowsky, 1979. Physiology of Woody Plant. Academic Press. New York. Sanfransisco. London.

Leksono, B. 1994. Variasi Genetik Produksi Getah Pinus merkusii Jungh et.de Vriese.
Tesis. Fakultas Kehutanan Universitas Gadjah Mada, Yogyakarta. tidak dipublikasikan.

Matheson, A. C. dan Raymond, C. A. 1984. The Impact of Genotype $\mathrm{x}$ Environment Interactions on Australian Pinus radiata Breeding Program.

Na'iem, M. 2000. Prospek Perhutanan Klon Jati di Indonesia. Prosiding Seminar Nasional Status Silvikultur di Indonesia Saat ini. Wanagama, Yogjakarta. 2000.

Shelbourne, C.J.A. 1972. Genotype-environment Interaction: Its Study and its Implications in Forestry Improvement. Proc. IUFRO Genetics-Sabrao Joint Symposia. Tokyo.

Siregar, I.Z. dan Mansur, I. 2004. Posisi Benih Unggul Versus Silvikultur Intensif Dalam Pembangunan Hutan Rakyat Jati. Makalah disampaikan dalam pertemuan Forum Komunikasi Jati, Tema Menjawab Tantangan Pengembangan Jati Rakyat dan Pemasarannya. Pusat Litbang Bioteknologi dan Pemuliaan Tanaman Hutan. Yogjakarta, 2004.

Siswamartana, S. dan Wibawa, A. 2005. Early Performance Clonal Test of Teak in Perum Perhutani. International Forestry Review. Vol 7 (5). 2005.

Sofyan, A. dan Syaiful, I. 2008. Pemeliharaan Jati (Tectona grandis) di KHDTK Kemampo. Laporan Penelitian. Balai Penelitian Kehutanan Palembang (tidak dipubikasikan).

Steel, R.G.D dan J.H. Torrie. 1991. Prinsip dan Prosedur Statistika. PT. Gramedia Pustaka Utama. Jakarta.

Russell, J.H. dan Libby, W.J. 1986. Clonal Testing Efficiency: The Trade-off Between Clone Tested and Ramet per Clone. Canadian Juornal of Forestry Research. Vol. 16. 1986.

Wibowo, A. 2002. Evaluasi Uji Klon Jati Pada Umur 15 bulan. Buletin Penelitian Pusbanghut. Vol V. No 03. 2002. Perum PERHUTANI. Pusat Pengembangan Sumberdaya Hutan Cepu.

Zobel, B.J. and. J. Talbert., 1984. Applied Forest Tree Improvement. John Wiley and Sons. New York. 